\title{
Conception rate and fecundity of Dohne Merino ewes in a continuous mating system
}

\author{
T.S. Brand ${ }^{1,2 \#}$, S. Terblanche ${ }^{1} \&$ J.W. Jordaan ${ }^{1}$ \\ ${ }^{1}$ Nelson Mandela Metropolitan University, George Campus: Saasveld, Private Bag X6531, George 6530, South Africa \\ ${ }^{2}$ Directorate: Animal Science, Western Cape Department of Agriculture, Private Bag X1, Elsenburg 7607, South Africa
}

(Received 4 January 2014; Accepted 5 June 2014; First published online 24 August 2014)

\begin{abstract}
Copyright resides with the authors in terms of the Creative Commons Attribution 2.5 South African Licence.
See: http://creativecommons.org/licenses/by/2.5/za

Condition of use: The user may copy, distribute, transmit and adapt the work, but must recognise the authors and the South African Journal of Animal Science.
\end{abstract}

\begin{abstract}
A study was conducted to evaluate the conception rate and fecundity of Dohne Merino ewes in an intensive sheep production system, where continuous mating was applied. The study was conducted at the Kromme Rhee research farm. Ninety-two 3-year-old Dohne Merino ewes were used in the trial and allocated to irrigated-lucerne equal-sized paddocks of 0.85 ha. Rotational grazing was applied at a stocking rate of 15 ewes per hectare, with rams left with the ewes continuously. A self-formulated creep feed and lick was provided to the lambs and ewes, respectively, on an ad libitum basis. The experimental animals were weighed every second week and lambs were weaned at approximately 120 days of age. The statistical procedures indicated that $65.4 \%$ of the ewes conceived within 81 days after lambing. Analyses of variance (ANOVA) were performed on the observed variables. The Shapiro-Wilk test was performed to test for normality and Student's-t least significant differences (LSD) were calculated at the $5 \%$ level of confidence, to compare the treatment means. Regression analyses were performed to establish the contribution of each variable to the predicted "days after lambing". The stepwise selection method was executed in order to select the variables that significantly contributed to the predicted "days after lambing". There was no significant difference in "days after lambing" and conception weight between ewes that produced single, twin or triplet lambs. Results also indicated that a more rapid breeding system is achievable on irrigated pastures. However, the sustainability of such a system needs to be tested further to determine the effect of the accelerated system on the productive lifespan of the ewes.
\end{abstract}

Keywords: Accelerated breeding, intensive sheep production, pastures

\# Corresponding author: tersb@elsenburg.com

\section{Introduction}

Global sheep numbers have declined over the past 10 years, with a number of factors contributing to this, namely predators, theft and the ever-present cost-price squeeze (Van Wyk, 2011). Due to the decline in numbers, prices of sheep products have shown a steady increase over the past few years (DAFF, 2012). These increases support the theory that when the demand is higher than supply, a change in the price levels can be expected for that product (Pride \& Ferrell, 1993). With the above phenomenon of numbers declining and prices of sheep products on the increase, certain structural changes can be expected within the sheep industry of South Africa. A renewed interest in producing sheep intensively on cultivated pastures in order to maximize the output per hectare has already been observed.

Intensive sheep production systems are based on the use of cultivated pastures, theoretically allowing for the practice of accelerated breeding systems. Since optimal feeding conditions can be provided to the lactating ewe, she can physiologically be prepared to ovulate and conceive whilst still in lactation (similar to a dairy cow); thus, allowing breeding to be accelerated so that, on average, more than one lambing opportunity per ewe per year can be obtained (Gaunt et al., 2010). Another contributing factor to the increased level of interest in accelerated breeding is the ability to produce lambs at times when sheep products are normally limited, allowing higher producer prices to be obtained (Fisher, 2001; de Nicolo, 2007).

This study was conducted to investigate the conception rate and fecundity of Dohne Merino ewes in an intensive, irrigated pasture-based sheep production system with a continuous mating strategy being applied. The aim of the study was thus to determine the conception rate and fecundity of Dohne Merino 
ewes under these conditions, as well as to identify which of the observed variables influenced the conception rate of the ewes.

\section{Materials and Methods}

The study was conducted at the Kromme Rhee research farm situated at a longitude 18050' east and latitude 3351' south in the Western Cape of South Africa, at an altitude of $177 \mathrm{~m}$ above sea level. The climate is classified as typically Mediterranean. The study was conducted using an existing flock of 92 threeyear old Dohne Merino ewes, with rams allocated at a ratio of $1: 50$ and left with the ewes continuously. The ewes grazed irrigated lucerne (Medicago sativa) pastures, which had been pre-established with the cultivar, SA Standard. The reason for the use of lucerne pasture is the superior quality; moreover, in a previous study, McGaveston (2012) identified that successful mating occurred when ewes graze young plant material, with the rate of twin-born lambs increasing by up to $20 \%$, compared to a grass based pasture. Irrigation was performed according to tensiometer readings and the use of an overhead sprinkler system. Irrigation commenced at a rate of $6 \mathrm{~mm}$ per day, when a reading of $40 \mathrm{kPa}$ was recorded and was suspended 5 days prior to grazing, in order to reduce the intake of parasites and to reduce the trampling effect of the animals on the pastures.

The paddocks were fenced to a similar size of 0.85 ha each, with rotational grazing being implemented. The pasture was then grazed according to the recommended resting times for lucerne of between 36 and 42 days (Iversen, 1967). The rotational system also exceeded the prescribed 26 days before returning to a camp and the grazing period of less than 21 days required to minimise the effect of internal parasites. A stocking rate of 15 ewes per hectare was maintained throughout the year.

The experimental animals had continuous access to fresh water and owing to the nature of lucerne pasture, the precautionary measure of adding sodium thiosulphate (Hypo) at $1 \mathrm{~kg}$ per $1000 \mathrm{~L}$ to the drinking water was taken, in order to decrease the risk of bloat. Nutritional management of the animals included the provision of supplementary feed to both the ewes and lambs. Ewes were provided with a self-formulated lick on an ad libitum basis, to which the suckling lambs also had access. A self-formulated creep feed to which the ewes did not have any access was provided ad libitum to the suckling lambs.

All lambs were weighed within 24 hours after birth and ear-tagged for identification. The dam, sex of the lamb (gender), litter size (birth status) and the birth date was recorded. All animals were weighed every second week and the lambs were weaned at approximately 120 days of age. Analyses of variance (ANOVA) were performed on observed variables using the SAS statistical software version 9.2. All variables were used to identify factors that may affect the conception rate of the ewes; this was expressed as "days after lambing". Production data of the experimental animals were calculated individually for all ewes and expressed as a percentage over the 12 month observation period.

\section{Results and Discussion}

Ewes used in this study lambed for the first time in March, 2011; data collection commenced thereafter. Rams were kept continuously with the ewes for a total period of 22 months, in order to determine the biological ability of the Dohne Merino ewes to conceive after lambing on cultivated pastures. The ability of the ewes to conceive after lambing is presented as the "days after lambing".

Production results for ewes obtained from this study over the 22 months' study period indicated that more than half $(56.6 \%)$ of the ewes in the flock conceived within 70 days of lambing and $44.0 \%$ of the flock conceived within 60 days after lambing (Figure 1). Smith et al. (1988) reported that ewes can conceive outside the normal breeding season with the use of hormonal and synchronization agents, such as CIDR (controlled internal drug release devices). In a study done by Horoz et al. (2003) it was found that a 95\% conception rate can be achieved when ewes are synchronized with the aid of melatonin. This result is higher than in the current study; however, the difference can be ascribed to the fact that all the ewes in the Horoz study were treated simultaneously. The result obtained from the present study was over a 22-month period, where all ewes were bred naturally.

According to Hafez (1974), sheep are seasonal breeders and will breed during less favourable conditions in order for the offspring to be born during favourable conditions when grazing is available in abundance. Dohne Merino ewes have been found to predominantly breed during February-May and September-December (Swanepoel, 2006), but this is generally determined by the feed flow system being implemented. In the results obtained from this study no evidence of seasonality could be confirmed due to the short duration of this study. Data covering a longer time period is required to confirm the possible seasonality of conception in Dohne Merino breeding ewes when maintained on cultivated pastures, under irrigation.

In this study, an annual fecundity (lambs born/ewes lambing) of $262 \%$ was recorded. This result is higher than values obtained by Fogarty et al. (1992) who reported fecundity values of $238 \%$ for an 8-month 
mating system with crossbred Merino ewes. Basson et al. (1969) reported a fecundity of $182 \%$ when Dohne Merino ewes were mated every eight months. A possible reason for the higher value obtained in this study than in the above mentioned studies is the level of genetic improvement during the time between execution of the different studies.

The nature of the Dohne Merino, as a dual-purpose breed, makes wool production an important factor to consider. Along with various other growth and reproductive variables, it was important to determine the annual wool production of an individual ewe when shorn every eight months and managed in a continuous mating system. On average ewes from the present study yielded $3.8 \mathrm{~kg}$ greasy wool per year. This is lower than that obtained by Basson et al. (1969) who recorded that Dohne Merino ewes produced $4.08 \mathrm{~kg}$ when shorn and lambing every 8 months. These results also indicated that an accelerated breeding system had no detrimental effect on wool production when proper nutrition was provided.

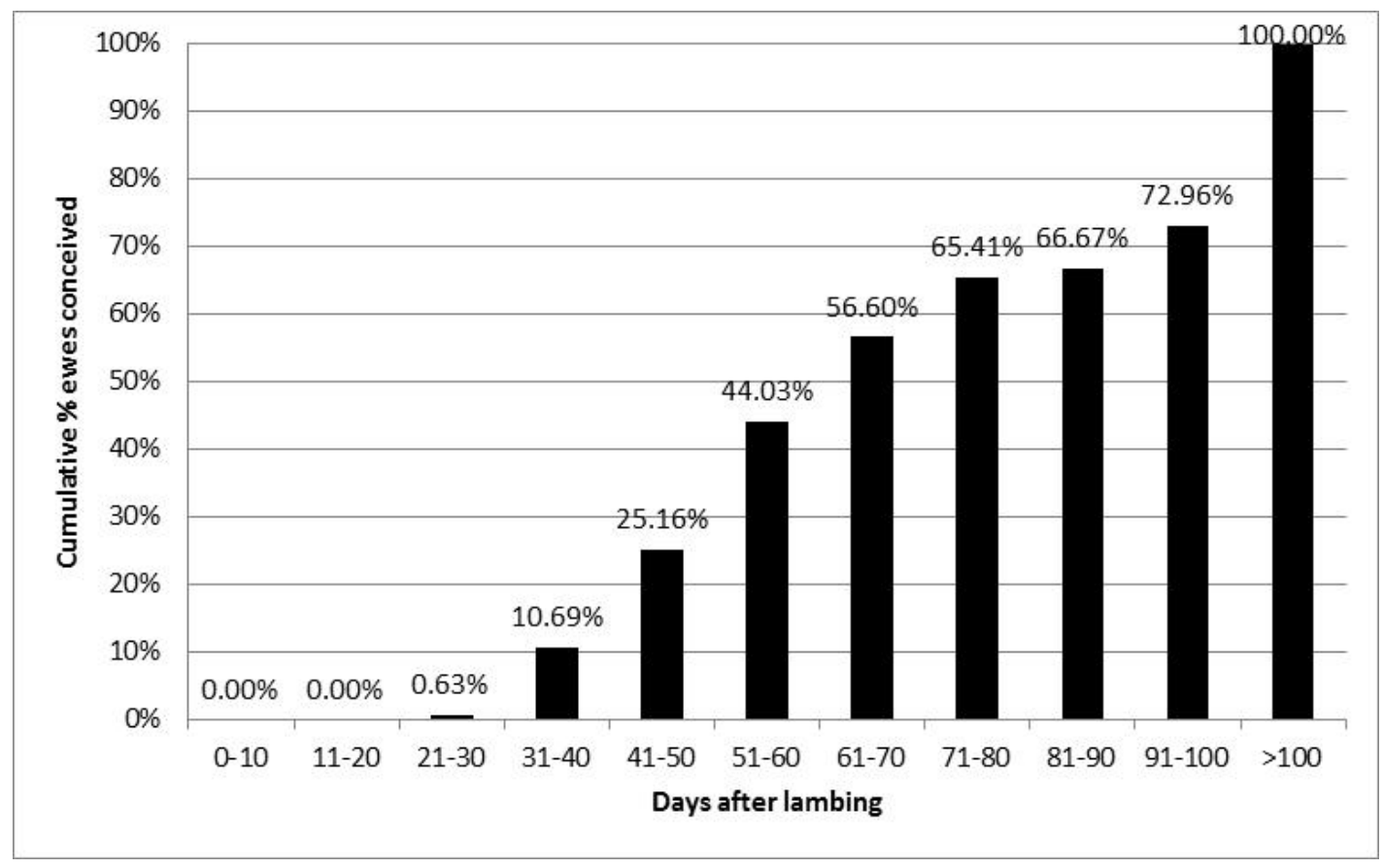

Figure 1 The cumulative percentage of Dohne Merino ewes that conceived in a continuous mating system.

One-way analyses of variance (ANOVA) were used to test the effect of the birth status and sex of the ewes' offspring on the observed variables measured during the ewes' next productive cycle. These included "days after lambing" for conception and conception body weight.

Birth status had no significant effect on either the lambing to conception interval (days after lambing) $(P=0.28)$ or conception weight $(P=0.41)$ (Table 1$)$. This phenomenon was contrary to expectations, as it could be argued that ewes with multiple lambs must produce more milk, resulting in a greater loss in live weight. This hypothesis is supported by Cloete et al. (2011), who identified that Merino ewes with multiples produced $21 \%$ more milk than ewes rearing singles.

Sex of lambs was tested as a possible factor influencing "days after lambing" and conception weight of the ewes. This was done in order to determine whether ewes with a ram lamb or a combination of ewe and ram lambs could conceive sooner. This was based on the speculation that pheromones secreted by the ewes or lambs could result in the lambing-conception interval being shorter in ewes with ram lambs than those with ewe lambs. Triplet-born lambs were removed from the statistical procedure, as the combinations of triplet-born lambs were not representative. No significant difference was observed between ewes with single-born ram or ewe lambs in the parameter "days after lambing" and dam conception body weight. No significant difference was obtained between ewes with twin-born lambs with a combination, including a ram lamb, for either "days after lambing" or conception body weight. Ewes with twin-born lambs with a combination of a ewe/ewe showed a significant difference to a ram/ewe combination for "days after lambing" and conception body weight. This tends to indicate that ewes bearing a ewe/ewe combination take longer to conceive. 
Table 1 The effect of birth status and sex of ewes' offspring for "days after lambing" and conception weight $($ mean \pm SD)

\begin{tabular}{lcc}
\hline Birth Status & Days after lambing & Conception weight $\mathbf{( k g )}$ \\
\hline 1 (Single) & $79.37^{\mathrm{a}} \pm 49.24$ & $70.92^{\mathrm{a}} \pm 9.02$ \\
2 (Twin) & $86.89^{\mathrm{a}} \pm 46.62$ & $69.42^{\mathrm{a}} \pm 10.19$ \\
3 (Triplets) & $114.75^{\mathrm{a}} \pm 68.15$ & $74.37^{\mathrm{a}} \pm 12.45$ \\
\hline LSD & 41.08 & 8.22 \\
\hline Sex & & $71.61^{\mathrm{a}} \pm 9.56$ \\
\hline 1-0 (Ram) & $75.55^{\mathrm{b}} \pm 44.40$ & $70.45^{\mathrm{ab}} \pm 6.27$ \\
1-1 (Ram/Ram) & $83.64^{\mathrm{ab}} \pm 53.38$ & $66.21^{\mathrm{b}} \pm 8.15$ \\
1-2 (Ram/Ewe) & $77.19^{\mathrm{b}} \pm 41.32$ & $73.33^{\mathrm{a}} \pm 12.43$ \\
2-2 (Ewe/Ewe) & $109.31^{\mathrm{a}} \pm 55.05$ & $69.96^{\mathrm{ab}} \pm 8.85$ \\
2-0 (Ewe) & $78.62^{\mathrm{b}} \pm 46.77$ & 5.40
\end{tabular}

${ }^{\#}$ Means with the same superscript are not significantly different.

Analyses of variance (ANOVA) on observed lamb variables tested the effect of gender, birth status and status/sex interaction on the time taken for ewes to conceive after lambing and observed variables of lambs (Tables 2 and 3). No significant interaction between litter status and sex was recorded for any of the observed lamb variables.

Table 2 The effect of sex (mean $\pm S D$ ) on the birth weight, weaning weight as well as average daily gain of Dohne Merino lambs in an accelerated breeding system on cultivated pastures under irrigation

\begin{tabular}{lccccc}
\hline Sex & $\mathbf{n}$ & Birth weight (kg) & $\mathbf{n}$ & $\begin{array}{c}\text { Weaning weight } \\
\text { (120 days)(kg) }\end{array}$ & $\begin{array}{c}\text { Average daily gain } \\
\text { (g/day) }\end{array}$ \\
\hline 1 (Ram) & 186 & $4.91^{\mathrm{a}} \pm 1.04$ & 160 & $37.91^{\mathrm{a}} \pm 5.93$ & $267^{\mathrm{a}} \pm 0.47$ \\
$2($ Ewe $)$ & 203 & $4.61^{\mathrm{b}} \pm 0.92$ & 172 & $34.78^{\mathrm{b}} \pm 5.62$ & $244^{\mathrm{b}} \pm 0.43$ \\
\hline LSD $(P=0.05)$ & 0.177 & 1.19 & 0.01 \\
\hline
\end{tabular}

$\overline{{ }^{a, b}}$ Significant $(P \leq 0.05)$ differences between observed variables.

Table 3 The effect of birth status (mean \pm SD) on the birth weight, weaning weight as well as average daily gains of Dohne Merino lambs in an accelerated breeding system on cultivated pastures under irrigation.

\begin{tabular}{lccccc}
\hline Birth status & $\mathbf{N}$ & $\begin{array}{c}\text { Birth weight } \\
\mathbf{( k g )}\end{array}$ & $\mathbf{n}$ & $\begin{array}{c}\text { Weaning weight } \\
(\mathbf{1 2 0} \text { days)(kg) }\end{array}$ & $\begin{array}{c}\text { Average daily gain } \\
\text { (g/day) }\end{array}$ \\
\hline (Single) & 138 & $5.30^{\mathrm{a}} \pm 0.94$ & 124 & $38.71^{\mathrm{a}} \pm 5.55$ & $270^{\mathrm{a}} \pm 0.44$ \\
2 (Twins) & 230 & $4.51^{\mathrm{b}} \pm 0.88$ & 191 & $34.85^{\mathrm{b}} \pm 5.74$ & $246^{\mathrm{b}} \pm 0.46$ \\
3 (Triplets) & 21 & $3.78^{\mathrm{c}} \pm 0.78$ & 17 & $34.78^{\mathrm{b}} \pm 6.01$ & $257^{\mathrm{ab}} \pm 0.50$ \\
\hline LSD $(P=0.05)$ & & 0.35 & & 2.40 & 0.019
\end{tabular}

$\overline{a, b}$ Significant $(P \leq 0.05)$ differences between observed variables.

The sex of lamb had a significant effect $(P=0.01)$ on lamb birth weight, as well as weaning weight over the 22-month study period. Male lambs were ca. $6.5 \%$ heavier at birth and ca. $8.9 \%$ heavier at weaning, compared to the ewe lambs. This result is supported by Bathaei \& Leroy (1998) and Cloete et al. (2001). The 
average daily gain (ADG) of the ram lambs was significantly higher than for the ewe lambs. The ADG for all sex types were higher than the ADG reported by Brand \& Franck (2000) of $0.236 \mathrm{~kg}$ at 100 days of age for the South African Mutton Merino when ewes were fed different nutrient levels. The ADG obtained in this study is also higher than the $0.216 \mathrm{~kg}$ reported by Schoeman (1990) for Dohne Merino ewes when lambs were weaned at 100 days. The average ADG obtained in the current study is $0.257 \mathrm{~kg}$.

Birth status also had a significant effect $(P \leq 0.01)$ on both birth weight and weaning weight with single lambs being heavier $(P \leq 0.05)$ than multiple lambs (twins/triplets) at birth and weaning. Single lambs were ca. $17.5 \%$ heavier than twins and ca. $40.2 \%$ heavier than triplets at birth. The birth weight of the twin-born lambs was ca. $19.3 \%$ heavier than that of the triplets. No significant difference $(P \geq 0.05)$ for body weight was obtained at weaning between twin and triplet lambs. These results are supported by that of Greeff et al. (2003), who reported that birth status had a significant influence on the birth and weaning weight of lambs. The ADG for single-born lambs was higher $(P \leq 0.01)$ than for twins and triplets. The ADG found in the present study is lower than that obtained by Coetzee \& Erasmus (1978) in an 8-month lambing system. They reported that single-born lambs' ADG was ca. $14.8 \%$ higher than that of twins. In this study no significant difference $(P \geq 0.05)$ in ADG between twin- and triplet-born lambs was recorded.

\section{Conclusion}

Intensive sheep production in South Africa is not common (Schoeman, 1990), although the practice is being applied on an increasing scale. High meat prices stimulate the practice of producing sheep under more intensive conditions, along with the cost-price squeeze pressuring producers to increase the efficiency of farming operations. The higher cost of production that accompanies an intensive production system, however, forces producers to adopt accelerated breeding in the production system to increase the amount of output obtained per ewe or per hectare.

Preliminary results from this study have shown that accelerated breeding can be practiced successfully on irrigated pastures in the Western Cape of South Africa. The current system can be seen as an alternative without the application of such intensive management as required in an 8-month lambing interval. This system relies on the availability of irrigated pastures and a feeding system as described, resulting in ewes being in optimal health. Consideration should be given to the practice of selection as Ingham (2003) identified that the conception rate in ewes is heritable. This then provides the opportunity to producers to select replacement ewes from dams that conceived within 60 days of lambing, resulting in genetic progress and enhanced accelerated breeding.

\section{Reference}

Basson, W.D., Van Niekerk, B.D.H., Mulder, A.M. \& Cloete, J.G., 1969. The productive and reproductive potential of three sheep breeds mated at eight monthly intervals under intensive feeding conditions. Proc. S. Afr. Soc. Anim. Prod. 8, 149.

Bathaei, S.S. \& Leroy, P.L., 1998. Genetic and phenotypic aspects of the growth curve characteristics in Mehraban Iranian fat-tailed sheep. Small Rumin. Res. 29, 261-269.

Brand, T.S. \& Franck, F., 2000. Production responses of two genetic different types of Merino sheep subjected to different nutritional levels. Small Rumin. Res. 37, 85-91.

Cloete, S.W.P., Greeff, J.C. \& Lewer, R.P., 2001. Environmental and genetic aspects of survival and early liveweight in Western Australian Merino sheep. S. Afr. J. Anim. Sci. 31, 123-130.

Cloete, S.W.P., Snyman, M.A. \& Scholtz, A.J., 2011. Genetic and environmental parameters of milk production and milk composition in South African Merinos. Proc. Assoc. Advmt. Anim. Breed. Genet. 19, 419-422.

Coetzee, J. \& Erasmus, L.S., 1978. Versnelde paringsfrekwensie met Dormers. Els. J. 2 (5), 21-24.

DAFF 2012. Department of Agriculture, Forestry and Fisheries (DAFF). Abstract of Agricultural Statistics, online available at http://www.nda.agric.za/docs/statsinfo/Abstract_2012.pdf

De Nicolo, G., 2007. Accelerated and out of season lamb production in New Zealand, PhD thesis, Massey University, New Zealand.

Fisher, M.W., 2001. An economic comparison of production systems for sheep. Can. J. Agric. Eco. 49, 327-336.

Fogarty, N.M., Hall, D.G. \& Atkinson, W.R., 1992. Productivity of 3 crossbred ewe types mated naturally at 8 months intervals over 2 years. Aust. J. Agric. Res. 43, 1819-1832.

Gaunt, G., Jolly, S. \& Duddy, G., 2010. Intensive Production Systems, Accelerated lambing. International Sheep and Wool Handbook, Nottingham University Press, United Kingdom, 565-580.

Greeff, J., Davidson, R. \& Skerrit, J., 2003. Genetic relationships between carcass quality and wool production traits in Australian Merino rams. Proc. Assoc. Advmnt. Anim. Breed. Gen. 15, 330-333. 
Hafez, E.S.E., 1974. Reproduction in Farm Animals. $3^{\text {rd }}$ Edition, Lea \& Febiger, Philadelphia. USA. pp. 265-274.

Horoz, H., Kasikci, G., Ak, K., Alkan, S. \& Sonmez, C., 2003. Controlling the breeding season using melatonin and progestragen in Kivircik ewes. Turk. Vet. ve Hayvancilik Dergisi. 27, 301-305.

Ingham, V.M., 2003. Genetic relationships affecting dual purpose use of Merino sheep. PhD thesis, University of Adelaide. Adelaide. Australia.

Iversen, C.E., 1967. Grazing Management of Lucerne. In: The Lucerne Crop, Wellington Reed. 129-133.

McGaveston, C., 2012. A review of reproductive performance of livestock if mating or flushing on lucerne. Lincoln University online available at http://www.lincoln.ac.nz/Documents/Dryland-PastureResearch/presentations/2013-2-19-Mating-and-flushing-sheep-on-lucerne.pdf

Pride, W.M. \& Ferrell, O.C., 1993. Marketing concepts and strategies, Setting Prices, Houghton Mifflin Company 8th Edition, U.S.A. 611-620.

Schoeman, S.J., 1990. Productivity of purebred Dohne Merino, S.A Mutton Merino and Dorper sheep under an intensive accelerated lambing system. Proc. $4^{\text {th }}$ Wrld Cong. Genet. Appl. Livest. Prod. Edinburgh. UK. 15 373-376.

Smith, J.F., Cruickshank, G.F., McGowan, L.T., Parr, J. \& Mortimer, B.J., 1988. Seasonal changes in oestrus, ovulation and conception of Coopworth ewes treated with CIDR's and PMSG. Proc. N. Z. Soc. Anim. Sci. 48, 99-102.

Swanepoel, J.W., 2006. A genetic evaluation of the Dohne Merino breed in South Africa. MSc dissertation. Stellenbosch University, South Africa.

Van Wyk, D.N., 2011. A quantitative analysis of supply response in the Namibian mutton industry, MSc dissertation. Stellenbosch University, South Africa. 